\title{
Determinants of Indonesia's National Income: An Auto-Regressive Distributed Lag Analysis
}

\author{
Prihartini Budi Astuti ${ }^{1^{*}}$, Nur Khasanah ${ }^{2}$ \\ ${ }^{*}$ Corresponding author
}

\begin{abstract}
At the end of 2019, most countries experienced an economic slowdown due to a trade war between the United States and China. According to macroeconomic theory, aggregate demand is one of the factors that influence economic growth. This study aims to add the debate and fill the gap by studying the relationship between aggregate demand and economic growth in the case of Indonesia. Using an Auto-Regressive Distributed Lag analysis, the results indicate that in the long-run, household consumption and investment had a positive effect on Indonesia's national income in 2010-2019. It means that the government must continue to make policies to maintain the purchasing power of Indonesian consumers, so that public consumption remains high, and maintaining the investment climate to be more conducive. On the other hand, government expenditure and net exports variables have no impact on Indonesia's national income in 2010-2019.
\end{abstract}

Keywords: household consumption, investment, government expenditure, net exports, auto-regressive distributed lag

\begin{abstract}
Abstrak
Pada akbir 2019, sebagian besar negara mengalami perlambatan ekonomi sebagai akibat dari perang dagang antara Amerika Serikat dan Cina. Menurut teori ekonomi makro, permintaan agregat adalah salah satu faktor yang mempengarubi pertumbuhan ekonomi. Tujuan dari penelitian ini adalah untuk menambah perdebatan dan mengisi kesenjangan dengan mempelajari hubungan antara permintaan agregat dan pertumbuhan ekonomi dalam kasus Indonesia. Dengan menggunakan analisis auto-regressive distributed lag, hasilnya menunjukkan bahwa dalam jangka panjang, konsumsi dan investasi rumah tangga memiliki efek positif terhadap pendapatan nasional Indonesia pada 2010-2019. Ini berarti bahwa pemerintah harus terus membuat kebijakan untuk mempertahankan daya beli konsumen Indonesia, sehingga konsumsi publik tetap tinggi, dan menjaga iklim investasi agar lebih kondusif. Di sisi lain, variabel pengeluaran pemerintah dan ekspor neto tidak berdampak pada pendapatan nasional Indonesia pada 2010-2019.
\end{abstract}

Kata Kunci: konsumsi rumah tangga, investasi, pengeluaran pemerintah, ekspor netto, auto-regressive distributed lag

JEL Classification: E01, E12, O47

How to Cite:

Astuti, P. B., \& Khasanah, N. (2020). Determinants of Indonesia's National Income: An Auto-Regressive Distributed Lag Analysis. Signifikan: Jurnal Ilmu Ekonomi, 9(2), 207-218. doi: http://doi.org/10.15408/sjie.v9i2.14469. 


\section{Introduction}

At the end of 2019, most countries experienced an economic slowdown as an impact of a trade war between the United States and China. Only the United States has continued to increase economic growth. In Quarter I-2019, the economy of the United States grew faster by 3.2 percent (y-o-y). This growth drive by public consumption that grew by 2.7 percent (y-o-y), specifically, consumption of goods (2.9 percent, y-o-y), and imports grew at a slower pace (1.6 percent, y-o-y). The Chinese economy grew steadily in Quarter I-2019 by 6.4 percent $(y-0-y)$. The completion of a trade war that has not yet reached an agreement holds back China’s economic growth (Bappenas, 2020).

The World Bank estimates that the global slowdown will suppress Indonesia's economic growth next year until 2020. This multilateral institution even projects that the Indonesian economy in 2020 will only reach $4.9 \%$ and will further slow down to a range of $4.6 \%$ in 2022 . The projected economic growth is far from the government's projections in the State Budget Draft (RAPBN), which predict to reach 5, 3\%. The global economic slowdown due to a trade war between the United States (US) and China that affects commodity prices will further affect Indonesia's economic growth. The World Bank (2019) projects the impact of a 1\% decline in Chinese economic growth on Indonesia's economic growth to reach $0.3 \%$.

Over the past ten years, there has been considerable academic interest in examining the relationship between aggregate demand (household consumption, investment, government spending, and net export) and economic growth (e.g., Zouhaier \& Karim, 2012; Frank et al., 2014; Wang et al., 2016; Musa \& Jelilov, 2016; Sultanuzzaman et al., 2019; Bakari, 2017; Sunde, 2017; Aslam, 2017; Nguyen, 2017, Fatemah \& Qayyum, 2018; Alper, 2018; Petkova, 2019; Amusa \& Oyinlola, 2019). Keynes's macroeconomic model shows the vital role of aggregate demand in determining a country's economic activity level. Keynes's analysis argues that the amount of sufficient demand determines a country's level of economic activity, that is, demand accompanied by the ability to pay for the goods and services requested. With the demand increase, it will also increase the production level produced by the company. This situation will cause an increase in the level of economic activity, the use of labor, and the use of production factors.

Alper (2018) has researched the relationship between household consumption and economic growth, which produced findings that there was a positive and significant relationship between household consumption and economic growth in Brazil, Russia, India, South Africa, and Turkey during the period 2005-2016. An increase of $1 \%$ in consumption expenditures increases economic growth by $0.41 \%$.

The relationship between investment and economic growth analyzed by Bakari (2018), who researched Algeria during 1969-2015. Using the Vector Error Correction Model, the equation of the long-run relationship shows that domestic investment has a negative effect on economic growth. Meanwhile, research from De Long \& Summers (1991), Madsen (2002), Borensztein et al. (1998), Zouhaier \& Karim (2012), and Sunde (2017) prove that there is a significant effect of investment on economic growth. 
The impact of government expenditure on economic growth had carried out by Frank et al. (2014). The study has the purpose of testing the existence of the Wagnerian hypothesis in Ghana and provides evidence on whether government expenditure plays any catalytic role in the growth of private investment by employing the ARDL model and Granger causality test with data spanning from 1970 to 2010 . The study concluded that long-run government expenditure has a significant positive impact on economic growth but has a negative impact on economic growth in the short-run.

The empirical study investigating the relationship between export and economic growth was carried out by Fatemah \& Qayyum in 2018. This study is an empirical investigation to export-led growth hypothesis (1971-2016) in the case of Pakistan by applying cointegration analysis and dynamic error correction mechanism. The study proves that exports are an essential and significant determinant of economic growth in Pakistan. The analysis also reveals that the exports, labor force, investment, and domestic credit to the private sector ratio are essential for the long-run and short-run economic growth of Pakistan. This study's results are not in line with the results of research from Bakari \& Mabrouki (2017) and Akalpler \& Shamadeen (2017), which found no relationship between exports and economic growth.

Previous studies show different results about the effect of aggregate demand on economic growth. Moreover, for the best of the author's current knowledge, there has been no research on the effect of overall aggregate demand on economic growth. The purpose of this study is to add the debate and fill the gap by studying the relationship between aggregate demand and economic growth in the case of Indonesia. Besides that, this research also contributes to giving recommendations for the policymaker on how to make economic growth higher than its current condition.

\section{Methods}

This study uses multiple regression analysis methods with the Auto-Regressive Distributed Lag (ARDL) model to analyze the effect of household consumption, investment, government expenditure, and net exports to economic growth in Indonesia in 2010-2019. The use of the ARDL model is because this study uses time-series data. Time series data are often not stationary, causing spurious regression. Spurious regression is when the regression results show a high coefficient of determination, but the relationship between variables in the model is not interconnected. The most appropriate model for time series data, not stationary, is the Error Correction Model (ECM). However, the ECM model can only be applied if the data are not stationary at the "level" but are stationary at the same level of data differentiation, and there is cointegration between the variables studied. If the variables studied have different levels of stationarity, then the ECM model cannot be applied. ARDL models can be used to overcome models with different levels of stationarity.

The ARDL model develops by Pesaran \& Shin (1998). The ARDL model was using when the variables studied have a level of stationarity at different levels. Data analysis using the ARDL approach carries out with the following steps. 


\section{Unit Root Test}

We can use the Dickey-Fuller test or the Augmented Dickey-Fuller test for unit root test. Other similar tests are the Dickey-Fuller DLS (ERS) test, the Phillips-Perron test, the Kwiatkowski-Philips-Schmidt-Shin test, the Elliot-Rothenberg-Stock Point-Optimal test, and the Ng-Perron test. All of them indicate the existence of a unit root as a null hypothesis. The unit root test in this study will use the Phillips-Perron test to determine whether the time series data contains unit roots or is non-stationary. The test of the root roots of the PhillipPerron is as follows:

$\Delta \mathrm{Y}_{\mathrm{t}}=\gamma \mathrm{Y}_{\mathrm{t}-1}+\mathrm{e}_{\mathrm{t}}$

$\Delta \mathrm{Y}_{\mathrm{t}}=\alpha_{0}+\gamma \mathrm{Y}_{\mathrm{t}-1}+\mathrm{e}_{\mathrm{t}}$

$\Delta \mathrm{Y}_{\mathrm{t}}=\alpha_{0}+\alpha 0+\gamma \mathrm{Y}_{\mathrm{t}-1}+\mathrm{e}_{\mathrm{t}}$

Where $\mathrm{t}$ is the time trend, a reasonably fast way to determine stationary or non-stationary data did by looking at the Probability value. To make the data not stationary into stationary, usually the data is sufficiently differentiated. If the first differentiation of data is not stationary, the second differentiation will be done.

\section{Cointegration Test}

The Cointegration test aims to determine the long-term relationship on the observed variables, whether cointegrated or not cointegrated. There are four cointegration test developments, namely: (1) cointegration test from Engle-Granger (EG); (2) Cointegrating Regression Durbin Watson (CRDW) test; (3) cointegration test developed by Johansen and (4) Bound Testing Approach. In this study the Bound Testing Approach cointegration test was used. To determine whether cointegration occurs or not, it is done by comparing the calculated $\mathrm{F}$ value with the upper bound or I value (1) at $\alpha=1 \%$. If the calculated $\mathrm{F}$ value is greater than the upper bound or I value (1) at $\alpha=1 \%$, then there is a cointegration between the variables studied.

\section{Auto-Regressive Distributed Lag Model}

Error Correction Model (ECM) and Auto-Regressive Distributed Lag (ARDL) is an option to be used to overcome the problem of time series data that is not stationary and the problem of spurious regression. The ECM model was first introduced by Sargan (1974) and developed by Hendry (1978) which was later popularized by Engle-Granger, while the ARDL model was developed by Pesaran and Shin (1998). The ARDL model equation can be written as follows:

$\sum_{i=1}^{n} \alpha 1 i \Delta Y t-1+\sum_{i=1}^{n} \alpha 21 \Delta C t-1+\sum_{i=1}^{n} \alpha 3 i \Delta I t-1+\sum_{i=1}^{n} \alpha 4 i \Delta G t-1+$

$\sum_{i=1}^{n} \alpha 51 \Delta X t-1+\theta 1 Y t-1+\theta 2 C t-1+\theta 3 I t-1+\theta 4 G t-1+\theta 5 X t-1+e t$

where $\Delta$ is the lag, the coefficient $\alpha 1 \mathrm{i}-\alpha 5 \mathrm{i}$ is the short-term relationship model and $\theta 1-\theta 5$ is the long-term dynamic relationship model. The important thing in estimating the ARDL model is determining the length of lags. The optimal length of lag can use the criteria from Akaike (Akaike Information Criterion = AIC) or use Schwarz (Schwarz Information 
Criterion $=$ SIC). Whether there is a long-term relationship between variables in the ARDL model is tested using the Bounds Testing Approach cointegration developed by Pesaran et al. (2001). This Bounds Testing Approach test is based on the statistical test F. The null hypothesis $\left(\mathrm{H}_{0}\right)$ and the alternative hypothesis $\left(\mathrm{H}_{\mathrm{a}}\right)$ of the Bound Testing Approach cointegration test can be written as follows:

$\mathrm{H}_{0}: \theta_{1}=\theta_{2}=\theta_{3}=\theta_{4}=\theta_{5}=0$

$\mathrm{H}_{\mathrm{a}}: \theta_{1} \neq \theta_{2} \neq \theta_{3} \neq \theta_{4} \neq \theta_{5} \neq 0$

The null hypothesis states there is no cointegration and the alternative hypothesis states there is cointegration between the variables studied.

\section{Result and Discussion}

The Central Bureau of Statistics on August 5, 2019, released figures for the Indonesian economy in the second quarter of 2019, were based on the Gross Domestic Product (GDP) that based on prevailing prices for the second quarter of 2019 reached IDR 3,963.5 trillion and based on the constant 2010 prices reached IDR 2,735.2 trillion. Indonesia's economy in the second quarter of 2019 compared to the first quarter of 2019 increased by 4.20 percent (q-to-q).

Gross Domestic Product (GDP) from the component of household consumption expenditure in the second quarter of 2019 measured at current prices reached IDR 2,211.3 trillion. With this value, household consumption still contributes the most to the national economy, which is more than 55\% of the national GDP. Meanwhile, if measured based on constant 2010 prices, public consumption grew 5.17\% to IDR $1,467.54$ trillion compared to the same quarter of the previous year. This growth was the highest in 21 quarters (Central Bureau of Statistics, 2019).

Economic growth in the second quarter of 2019 was also influenced by improved investment performance, both in construction and non-building investment. The Investment Coordinating Board (BKPM) said that investment realization for the second quarter of 2019 reached IDR 200.5 trillion, an increase of $13.7 \%$ compared to the same period in 2018 . The total investment contributed $25.3 \%$ to the target year 2019, amounting to IDR 792 trillion. The investment achievements in this period succeeded in absorbing 255,314 Indonesian workers (The Investment Coordinating Board, 2019).

Government expenditure in the 2019 APBN plan to be IDR 2,461.1 trillion consisting of central government expenditure of IDR 1,634.3 trillion, ministry/agency expenditure of Rp855.4 trillion, non-ministerial/institutional expenditure of Rp778.9 trillion and transfers to the regions \% Of Village Funds IDR 826.8 trillion (Ministry of Finance, 2019).

The last component of aggregate demand is net exports. The Central Bureau of Statistics (BPS) recorded that Indonesia's exports in August 2019 reached US\$ 14.28 billion, down 7.60 percent compared to exports in July 2019. Cumulatively, the value of Indonesia's exports from January to August 2019 reached US\$ 110.07 billion, down 8.28 percent over the same period in 2018, as well as non-oil and gas exports reached US\$101.48 billion or decreased 6.66 percent. On the other hand, the value of Indonesia's imports in August 2019 
reached US\$ 14.20 billion, down 8.53 percent compared to July 2019, as well as compared to August 2018, down 15.60 percent (The Central Bureau of Statistics, 2019).

Table 1 shows the results of the Unit Root Test conducted on the variables in this study using the Phillips-Perron test. Table 1 shows that the variable GDP, household consumption, and investment are stationary at the "first difference" stage, while the government expenditure and net export are stationary at the "level" stage.

Table 1. Unit Root Test Results with the Phillips-Perron Test

\begin{tabular}{clcccc}
\hline \multirow{2}{*}{ No. } & & \multicolumn{2}{c}{ Level } & \multicolumn{2}{c}{ First Difference } \\
\cline { 3 - 5 } & & Adj.t-stat & Prob. & Adj.t-stat & Prob. \\
\hline 1. & GDP & 0.115 & 0.962 & -7.856 & 0.000 \\
2. & Household Consumption & 1.030 & 0.996 & -10.978 & 0,000 \\
3. & Investment & -1.114 & 0.699 & -13.832 & 0.000 \\
4. & Government Expenditure & -7.586 & 0.000 & - & - \\
5. & Net Exports & -5.087 & 0.000 & - & - \\
\hline
\end{tabular}

Source: Data Processing

Table 2 shows the calculated $\mathrm{F}$ value of 5.149122, with a degree of freedom of 4 . The calculated $F$ value is higher than the upper bound, or I value (1) at $\alpha=1 \%$ (4.37). The results of this test indicate that there is cointegration between the variables studied. This result means that each variable can use to know that model has a long-term equilibrium relationship, and the variables have been stationary, meaning that between the independent and dependent variables are cointegrated or have a long-term relationship. These results are in line with the results of research from Wang et al. (2016), Sun \& Deng (2013), Akalpler \& Shamadeen (2017), and Sunde (2017).

Table 2. Bound Testing Approach Cointegration Test Results

\begin{tabular}{ccccc}
\hline F-Bound Test & \multicolumn{3}{c}{ Null Hypothesis : No levels relationship } \\
\hline Test Statistic & Value & Signif. & I (0) & I (1) \\
\hline F-statistic & 5.149 & $10 \%$ & 2.2 & 3.09 \\
& 4 & $5 \%$ & 2.56 & 3.49 \\
& & $2.5 \%$ & 2.88 & 3.87 \\
& & $1 \%$ & 3.29 & 4.37 \\
\hline
\end{tabular}

Source: Data Processing

The next step is to estimate the short-term ARDL model with the ECM ARDL model. The error correction variable, which is the error of the previous period, is indicated by the CointEq(-1) variable. The error correction variable value is negative and significant, meaning that the ARDL ECM model is valid and shows the cointegration between the dependent 
and independent variables. The use of the ARDL ECM model is to estimate the shortterm ARDL model. The Error Correction Model (ECM) can derive from the ARDL model through a simple linear transformation, which integrates short-run adjustments with longrun equilibrium without losing long-run information. The associated ECM model takes a sufficient number of lags to capture the data generating process in general to specific modeling frameworks (Nkoro \& Uko, 2016).

Table 3. Short-term ARDL Model Estimation

\begin{tabular}{|c|c|c|c|c|}
\hline \multicolumn{5}{|c|}{$\begin{array}{l}\text { ECM Regression } \\
\text { Case 2: Restricted Constant and No Trend }\end{array}$} \\
\hline Variable & Coefficient & Std.Error & t-Statistic & Prob. \\
\hline $\mathrm{D}(\mathrm{PDB}(-1))$ & 0.197 & 0.191 & 1.029 & 0.327 \\
\hline $\mathrm{D}(\mathrm{PDB}(-2))$ & -0.157 & 0.144 & -1.086 & 0.302 \\
\hline $\mathrm{D}(\mathrm{PDB}(-3))$ & -0.518 & 0.112 & -4.624 & 0.000 \\
\hline D(CONSUMPTION) & 1.391 & 0.283 & 4.916 & 0.000 \\
\hline D(CONSUMPTION(-1)) & -0.116 & 0.474 & -0.244 & 0.811 \\
\hline D(CONSUMPTION(-2)) & -0.183 & 0.192 & -0.954 & 0.362 \\
\hline D(CONSUMPTION(-3)) & 0.761 & 0.167 & 4.548 & 0.001 \\
\hline D(INVESTMENT) & 0.113 & 0.068 & 1.656 & 0.128 \\
\hline D(INVESTMENT(-1)) & -0.327 & 0.115 & -2.824 & 0.018 \\
\hline D(INVESTMENT(-2)) & -0.239 & 0.078 & -3.027 & 0.012 \\
\hline $\mathrm{D}(\mathrm{GE})$ & -0.184 & 0.065 & -2.815 & 0.018 \\
\hline $\mathrm{D}(\mathrm{GE}(-1))$ & 0.115 & 0.069 & 1.657 & 0.128 \\
\hline $\mathrm{D}(\mathrm{GE}(-2))$ & 0.258 & 0.073 & 3.537 & 0.005 \\
\hline $\mathrm{D}(\mathrm{GE}(-3))$ & 0.162 & 0.074 & 2.198 & 0.052 \\
\hline D(NET_EXPORT) & 0.040 & 0.034 & 1.200 & 0.257 \\
\hline D(NET_EXPORT(-1)) & -0.103 & 0.035 & -2.941 & 0.014 \\
\hline D(NET_EXPORT(-2)) & -0.106 & 0.032 & -3.278 & 0.008 \\
\hline D(NET_EXPORT(-3)) & -0.042 & 0.026 & -1.593 & 0.142 \\
\hline CointEq(-1)* & -1.109 & 0.163 & -6.807 & 0.000 \\
\hline R-squared & 0.999 & Mean dependent var & & 29342.84 \\
\hline Adjusted R-squared & 0.998 & S.D. dependent var & & 54415.93 \\
\hline S.E. of regression & 2071.864 & Akaike info criterion & & 18.409 \\
\hline Sum squared resid & 64389327 & Schwarz criterion & & 19.263 \\
\hline Log likelihood & -293.963 & Hannan-Quinn criter. & & 18.700 \\
\hline Durbin-Watson stat & 2.465 & & & \\
\hline
\end{tabular}

Source: Data Processing 
The model selection results using the AIC value stated that the ARDL model $(3,3,2$, 3, 3) was the best model with the smallest Akaike Information Criterion value of 18.40962. The Adjusted R Square value of 0.9985 shows that each independent variable can explain $99.85 \%$ of the dependent variable's variation in the selected ARDL model. The estimation test results of the short-term ARDL model in Table 3 show that the value of CointEq $(-1)=$ -1.109 and significant at the $5 \%$ level (Prob 0.0000). This result means that there is a shortterm cointegration in this model. The CointEq coefficient then uses to measure the speed of adjustment, which is the speed of adjustment in response to changes. With a CointEq value of 1.109 means that in this study, the ARDL model $(3,3,2,3,3)$ has fulfilled the validity requirements, so it can conclude that the model will go to equilibrium at a speed of 11,09 percent per month.

In the short-run, all independent variables influence economic growth. In short-term, household consumption and government expenditure have a positive effect on economic growth, which shows the same results as the research from Wang et al., 2016; Petkova, 2019; Alper, 2018; Sun \& Deng (2013), but not in line with the research by Amusa \& Oyinlola (2019) and Okoye et al. (2019) which shows that in the short-run government expenditure has a negative effect to economic growth. Different results show by investment and net export variables, which negatively affect the short-run economic growth in Indonesia in 2010-2019. The negative influence of investment and net exports variables on economic growth is in line with research from Chimobi (2010), Nguyen (2017) and Bakari (2018), but not in line with the research by Nguyen (2016) that found that in the short-run, export has a positive effect to economic growth.

The final step is the estimation of the long-term ARDL model in Table 4. From the estimation results of the long-term ARDL model in Table 4, we can arrange it into the following equation:

GDP $=1.550334($ H.CONSUMPTION) + 0.526198 (INVESTMENT) -0.307575 (GE) + 0.178538

(NET_EXPORT) + 39926.5919

Table 4. Estimation of the Long-Term ARDL Model

Levels Equation

Case 2: Restricted Constant and No Trend

\begin{tabular}{ccccc}
\hline Variables & Coefficient & Std.Error & t-Statistic & Prob. \\
H.CONSUMPTION & 1.550 & 0.122 & 12.659 & 0.000 \\
INVESTMENT & 0.526 & 0.197 & 2.668 & 0.023 \\
GE & -0.307 & 0.266 & -1.152 & 0.276 \\
NET_EXPORT & 0.178 & 0.139 & 1.284 & 0.228 \\
C & 39926.59 & 29335.87 & 1.361 & 0.203 \\
EC $=$ PDB $-(1.5503 *$ H.CONSUMPTION + 0.5262*INVESTMENT -0.3076*GE + 0.1785*NET_EXPORT + \\
39926.5919)
\end{tabular}


The equation shows that the household consumption variable has the most significant coefficient value of 1.550, which means that the household consumption variable is the dominant factor affecting the level of Indonesia's national income from 2010-2019. Increasing household consumption by $1 \%$ will increase national income by $1.5 \%$. These results are in line with the results of research by Alper (2018), Aslam (2017) and Petkova (2017), as well as increasingly proving the importance of the role of household consumption in increasing economic growth in a country, because increasing household consumption will also affect investment increases and decreasing unemployment rates.

The next variable that has a positive and significant effect on Indonesia's national income 2010-2019, in the long run, is the investment variable, with a coefficient value of 0.526198 , which means an increase in investment of $1 \%$ will increase national income by $0.5 \%$. The effect of investment on economic growth in this study is in line with the results of research from De Long \& Summers (1991), Madsen (2002), Borensztein et al. (1998), Zouhaier \& Karim (2012) and Sunde (2017) which prove that there is a significant effect of investment on economic growth. This result also proves Keynes's analysis that states that investment is one of the determinants of a country's economic growth because, with an increase in investment, it will increase the amount of production of goods and services that will ultimately lead to economic growth.

Different results are shown by the government expenditure (GE) variable, which has a negative but not significant effect in the long run on Indonesia's national income in 2010-2019. This result is not in line with the research of Wu et al. (2010), Musa \& Jelilov (2016), Dudzevičiūtè et al. (2017), Amusa \& Oyinlola (2019) which found that government expenditure has a positive effect on economic growth in the long run. The influence of government spending on economic growth in this study has the same direction as the research results from Hasnul (2015) and Okoye et al. (2019).

The last independent variable in this research is net export. The analysis results show that net export has a positive but not significant effect on Indonesia's national income in 2010-2019. This condition can occur because Indonesia's trade balance often experiences a deficit. This result is not in line with Bakari (2017), Nguyen (2017), Sultanuzzaman et al. (2019), Lin \& Li (2003), and Mo (2010), which show that in the long run, exports have a negative effect on economic growth. The results of this study are more in line with the results of research from Bakari \& Mabrouki (2017) and Akalpler \& Shamadeen (2017), which found that there is no relationship between exports and economic growth.

\section{Conclusions}

This study's results indicate that household consumption and investment have a positive effect on Indonesia's economic growth in 2010-2019, while government expenditure and net exports show different results. The government expenditure has a negative effect, while the net export variable has a positive but not significant effect on Indonesia's economic growth in 2010-2019. 
Two policy recommendations can suggest as a result of the study. Firstly, the government must continue to make policies to maintain the purchasing power of Indonesian consumers, so that public consumption remains high. Policies that can carry out include providing subsidies to the community (e.g., subsidies on health, education, electricity) and tax relief for people whose income is still low. Secondly, maintaining the investment climate to be more conducive, for example, by facilitating investment licensing (one-stop service), maintaining political stability and security, and providing tax incentives for new investors. It expects that with these two policies, the amount of investment will increase so that the contribution to economic growth is more significant than before.

\section{References}

Akalpler, E., \& Shamadeen, B. (2017). The Role of Net Export on Economic Growth in United States of America. Journal of Applied Economic Sciences, 12(3), 772-781.

Alper, A. E. (2018). The Relationship of Economic Growth with Consumption, Investment, Unemployment Rates, Saving Rates and Portfolio Investments in The Developing Countries. Gaziantep University Journal of Social Sciences, 17(3), 980-987.

Amusa, K., \& Oyinlola, M. A. (2019). The Effectiveness of Government Expenditure on Economic Growth in Botswana. African Journal of Economic and Management Studies, 10(3), 368-384. https://doi.org/10.1108/AJEMS-03-2018-0081

Aslam, A. L. (2017). Does Consumption Expenditure Induce the Ecomonic Growth? an Empirical Evidence from Sri Lanka. World Scientific News, 81(2), 221-234.

Bakari, S. (2017). The Impact of Domestic Investment on Economic Growth: New Evidence from Malaysia. Munich Personal RePEc Archive Paper No. 79436. https://mpra.ub.unimuenchen.de/id/eprint/79436

Bakari, S. (2018). The Impact of Domestic Investment on Economic Growth New Policy Analysis from Algeria. Bulletin of Economic Theory and Analysis, 3(1), 35-51.

Bakari, S., \& Mabrouki, M. (2017). Impact of Exports and Imports on Economic Growth: New Evidence from Panama. Journal of Smart Economic Growth, 2(1), 67-79.

Bappenas. (2020). Indonesia and World Economic Development Report Quarter IV 2019. (Publication Vol. 3 No. 4, February 2020). Retrieved from https://www.bappenas. go.id/files/2715/8529/3891/Laporan_Perkembangan_Ekonomi_Indonesia_dan_ Dunia_Triwulan_IV_2019.pdf.

Borensztein, E., De Gregorio, J., \& Lee, J. W. (1998). How Does Foreign Direct Investment Affect Economic Growth?. Journal of international Economics, 45(1), 115-135. https:// doi.org/10.1016/S0022-1996(97)00033-0.

Central Bureau of Statistics. (2019). Official Statistics News: 05 August 2019. Retrieved from https://www.bps.go.id/pressrelease/2019/08/05/1621/ekonomi-indonesia-triwulan-ii2019-tumbuh-5-05-persen.html

Chimobi, O. P. (2010). The Estimation of Long-run Relationship between Economic Growth, Investment and Exports in Nigeria. International Journal of Business and Management, 5(4), 215-222. 
De Long, J. B., \& Summers, L. H. (1991). Equipment Investment and Economic Growth. The Quarterly Journal of Economics, 106(2), 445-502.

Dudzeviit, G., Šimelyt, A., \& Liuvaitien, A. (2018). Government Expenditure and Economic Growth in the European Union Countries. International Journal of Social Economics, 45(2), 372-386. https://doi.org/10.1108/IJSE-12-2016-03365.

Fatemah, A., \& Qayyum, A. (2018). Modeling the Impact of Exports on the Economic Growth of Pakistan. Turkish Economic Review, 5(1), 56-64.

Frank, A., Joseph, O. M., \& Ackah, I. (2014). Government Expenditures and Economic Growth Dynamics in Ghana. International Journal of Economics and Empirical Research (IJEER), 2(5), 180-190.

Hasnul, A. G. (2015). The Effects of Government Expenditure on Economic Growth: The Case of Malaysia. Munich Personal RePEc Archive Paper No. 71254. https://mpra. ub.uni-muenchen.de/id/eprint/71254

Lin, J. Y., \& Li, Y. (2003). Export and Economic Growth in China: A Demand-Oriented Analysis. China Economic Quarterly, 2, 779-794.

Madsen, J. B. (2002). The Causality between Investment and Economic Growth. Economics Letters, 74(2), 157-163. https://doi.org/10.1016/S0165-1765(01)00549-3.

Ministry of Finance of the Republic of Indonesia. (2019). APBN 2019: Fair, Healthy and Independent Encouraging Investment and Indonesian Competitiveness through Human Resource Development. Retrieved from https://www.kemenkeu.go.id/apbn2019

Mo, P. H. (2010). Trade Intensity, Net Export, and Economic Growth. Review of Development Economics, 14(3), 563-576. https://doi.org/10.1111/j.1467-9361.2010.00573.x.

Musa, M., \& Jelilov, G. (2016). The Impact of Government Expenditure on Economic Growth in Nigeria. Sacha Journal of Policy and Strategic Studies, 15(2), 15-23.

Nguyen, T. H. (2016). Impact of Export on Economic Growth in Vietnam: Empirical Research and Recommendations. International Business and Management, 13(3), 45-52.

Nguyen, N. T. K. (2017). The Long-Run and Short-Run Impacts of Foreign Direct Investment and Export on Economic Growth of Vietnam. Asian Economic and Financial Review, 7(5), 519-527.

Nkoro, E., \& Uko, A. K. (2016). Autoregressive Distributed Lag (ARDL) Cointegration Technique: Application and Interpretation. Journal of Statistical and Econometric Methods, 5(4), 63-91.

Okoye, L. U., Omankhanlen, A. E., Okoh, J. I., Urhie, E., \& Ahmed, A. (2019). Government Expenditure and Economic Growth: The Case of Nigeria. Proceedings of SOCIOINT, 1184-1194.

Pesaran, M. H., \& Shin, Y. (1998). An Autoregressive Distributed-Lag Modelling Approach to Cointegration Analysis. Econometric Society Monographs, 31, 371-413.

Pesaran, M. H., Shin, Y., \& Smith, R. J. (2001). Bounds Testing Approaches to the Analysis of Level Relationships. Journal of Applied Econometrics, 16(3), 289-326. https://doi. org/10.1002/jae.616. 
Petkova, A. (2017). The Role of Household Consumption in Relationship Between Economic Growth and Foreign Direct Investment in Bulgaria. Economics, 2, 163-170.

Sultanuzzama, M. R., Fan, H., Mohamued, E. A., Hossain, M. I., \& Islam, M. A. (2019). Effects of Export and Technology on Economic Growth: Selected Emerging Asian Countries. Economic Research, 32(1), 2515-2531. https://doi.org/10.1080/1331677X. 2019.1650656.

Sun, X. X., \& Deng, L. L. (2013). An Empirical Analysis on the Influence of Household Consumption on Economic Growth in Hubei Province. In The 19th International Conference on Industrial Engineering and Engineering Management (pp. 41-51). Springer, Berlin, Heidelberg.

Sunde, T. (2017). Foreign Direct Investment, Exports and Economic Growth: ADRL and Causality Analysis for South Africa. Research in International Business and Finance, 41, 434-444. https://doi.org/10.1016/j.ribaf.2017.04.035.

The Investment Coordinating Board of the Republic of Indonesia. (2019). Realization of Investment in the Second Quarter of 2019 Breaks through the Two Hundred Trillion Rupiah. Retrieved from https://www.bkpm.go.id/images/uploads/ppid/file_upload/ Realisasi_Penanaman_Modal_TW_2_2019.pdf

Wang, Y., Zhang, Y., \& Liu, Q. (2016). The Research on the Relationship of Domestic Investment, Government Consumption, Household Consumption and Economic Growth-an Empirical Study of Fujian Province. International Journal of Database Theory and Application, 9(3), 47-60.

World Bank. (2019). Global Economic Prospects. Washington: World Bank Publication

Wu, S. Y., Tang, J. H., \& Lin, E. S. (2010). The Impact of Government Expenditure on Economic Growth: How Sensitive to the Level of Development?. Journal of Policy Modeling, 32(6), 804-817. https://doi.org/10.1016/j.jpolmod.2010.05.011.

Zouhaier, H., \& Karim, K. M. (2012). Democracy, Investment and Economic Growth. International Journal of Economics and Financial Issues, 2(3), 233-240. 